\title{
Link between diet and cardiovascular disease in Latin America and the Caribbean using geographic information systems
}

\author{
Jennifer MacDonald, ${ }^{1}$ Patricia B. Brevard, ${ }^{2}$ Robert E. Lee, ${ }^{3}$ \\ and Tammy Wagner ${ }^{2}$
}

Suggested citation

MacDonald J, Brevard PB, Lee RE, Wagner T. Link between diet and cardiovascular disease in Latin America and the Caribbean using geographic information systems. Rev Panam Salud Publica. 2009; 26(4):290-8.

ABSTRACT Objective. To determine the visual, spatial, and/or statistical relationships between food availability/dietary patterns and cardiovascular disease (CVD) in Latin America and the Caribbean (LAC).

Methods. CVD mortality rates and diet information (the number of kilocalories and amount of alcohol, fats, fish, fruits, meats, sugars, and vegetables available per person daily) were obtained from internationally available databases. The analyses included 32 LAC countries with sufficient data (15 of 47 had been excluded for incomplete data). Pearson's correlations $(r)$ were used to determine relationships between diet and CVD mortality, and multiple linear regression analysis was conducted to identify predictors of mortality. ArcGIS version 9.2 (Environmental Systems Research Institute, Inc., Redlands, California, United States) was used to construct maps to explore visual relationships between CVD and diet.

Results. No relationships were found between CVD and alcohol, fruit, meat, sugar, or vegetable intake. Statistically significant, positive correlations were found between oil-crops $(\mathrm{r}=0.680, \mathrm{P}=0.000)$ and fish and seafood $(\mathrm{r}=0.411, \mathrm{P}=0.019)$ and CVD mortality. Regression analysis revealed that high kilocalorie availability was a predictor of low CVD mortality $(\mathrm{P}=0.020)$. High oil-crop availability was a predictor of high CVD mortality $(\mathrm{P}=0.000)$. Maps constructed show visual relationships between availability of fish and seafood, kilocalories, and oil-crops, and CVD mortality.

Conclusions. Fish and seafood, kilocalorie, and oil-crop availability appear to be related to CVD mortality, but further investigation is needed. Associations between diet and CVD mortality create the opportunity to target specific countries for nutrition education and CVD prevention programs.

Key words Cardiovascular diseases; diet; food consumption; geographic information systems; mortality; Latin America; Caribbean Region.

\footnotetext{
${ }^{1}$ Rockingham Memorial Hospital, Nutrition Services, Harrisonburg, Virginia, United States of America.

${ }^{2}$ James Madison University, Health Sciences, Harrisonburg, Virginia, United States. Send correspondence to: Dr. Patricia B. Brevard, James Madison University, Health Sciences, MSC 4301, Harrisonburg, VA 22807, United States of America; telephone: +01-540-568-6362; fax: +01-540-568-3336; email: brevarpb@jmu.edu

3 James Madison University, Mathematics and Statistics, Harrisonburg, Virginia, United States.
}

Cardiovascular disease (CVD) became the leading cause of death worldwide in the mid-1990s, with 29 million deaths in a single year (1). In developing countries, CVD incidence has been on the rise since the late 1980s (1); by 1990, these countries were experiencing $63 \%$ of the total, global CVD deaths (2). The in- crease in CVD-related mortality is evident throughout Latin America and the Caribbean (LAC). CVD is currently the leading cause of death in almost every country in the area, with $31 \%$ of all deaths attributed to CVD and an increase of $60 \%$ expected in the period from 2000-2020 (3). Projections for the 
next two decades identify CVD as the leading cause of disability, surpassing infectious and parasitic diseases as causes (1). It has been reported that, in LAC, approximately 20.7 million individuals will die of CVD in the next 10 years (3), with $23 \%$ of these deaths occurring among those less than 60 years of age (4). In addition, mortality due to specific CVDs, such as ischemic heart disease and stroke, will triple $(3,5)$. Predictions such as these, along with rising incidence rates, are indicative of a major public health problem in LAC, one that needs to be addressed if it is to be controlled.

The Atlas of Heart Disease and Stroke, produced by the World Health Organization (WHO) in collaboration with the United States Centers for Disease Control and Prevention (CDC), indicates that there are more than 300 risk factors associated with CVD and stroke (6). Major, modifiable risk factors for CVD include diet, elevated glucose, elevated low density lipoprotein (LDL), high blood pressure, low levels of high density lipoprotein (HDL), obesity, physical inactivity, stress, and tobacco consumption $(6,7)$. Furthermore, Yusuf and colleagues (7) hypothesize that the interactions between genetic and environmental changes may be largely attributable to urbanization and greater affluence, in addition to a wide range of influential factors throughout the life cycle. Many studies identify diet as a major contributor to the burden of CVD. Bermudez and Tucker (8) state that with gradual changes in diet, CVD prevalence and its major risk factors-diabetes, obesity, and hypertension-began to rise. Ezzati and colleagues (9) identify nutrition-related risk factors, such as high blood-pressure, high cholesterol, overweight/obesity, and low fruit and vegetable intake, as major contributors to ischemic heart disease and stroke, underscoring the importance of studying diet in relation to CVD.

The present study focuses on dietary variables as major risk factors that can be modified to reduce the risk of CVD (10). Unfortunately, there is limited information on dietary intake, and available epidemiological data are incomplete for individual LAC countries, making it difficult to address this aspect of the CVD crisis $(11,12)$. Nicholls and colleagues (11) state that mortality data for each country is difficult to find due to low coverage by death registries and poorly defined diagnoses stating cause of death. It is estimated that only $55 \%-60 \%$ of the LAC population has complete vital registration data; the remainder must use indirect methods, such as models of transition and community-level studies (12). Research that has been conducted to date is inadequate, and limitations have been found with the population or are under study. Bermudez and Tucker (8) investigated food intake trends in different parts of Latin America, and concluded that there were potential links to rising CVD. Consumption of cereal, roots, fiber, fruits, vegetables, and tubers has declined, while intake of animal proteins, fats, sugars, and processed foods has increased over the past 10 years (8). This transition in food intake, and therefore nutrient intake, puts the entire area at increased risk of CVD.

An obstacle making it particularly difficult to encourage change within individual countries is that Latin America is divided into six geographic areas. Bermudez and Tucker (8) consider LAC as either a single group or geographic subgroups, when in fact it consists of approximately 47 independent countries, with a host of different cultures and ethnicities (13). Therefore, combining the broad range of diets and food habits may lead to inaccurate conclusions regarding nutrition-related CVD risk factors. There are also contradictory results regarding the content of the Caribbean diet $(8,14)$. Greenberg and colleagues (14) reported that the Caribbean diet is cardio-protective, whereas Bermudez and Tucker (8) suggest that the transition to a diet of excess calories, fat, and processed foods has increased the risk of $\operatorname{CVD}(8,15,16)$. Lack of data on dietary intake and CVD incidence in these countries, in addition to differing results in the current literature, point to a need for further study.

Geographic Information Systems (GIS) is an analysis technique used by many professionals to determine patterns within communities and small groups that impact public health concerns, risks, and outcomes (17). GIS allows for the observation of large amounts of data, which makes it easier to identify patterns (18). This technique is becoming more widely used to understand and determine the needs of specific communities or geographic areas, especially when planning health and research activities $(17,19,20)$. Data collected from specific populations, communities, or existing GIS databases are grouped according to demographic characteristics, such as census records, food tables, or even grocery store locations (18). The collected information is then converted into raw numbers and combined in different ways to create maps that visually display the data (18). By creating and overlapping multiple maps, the individual relationships between specific factors, such as dietary intake and CVD mortality, can be shown, as well as how these factors might act upon one another.

In order to address the problem of CVD in LAC, there is a need to focus on individual countries and determine dietary intake patterns related to CVD incidence in each. Therefore, this study investigated the dietary composition of each LAC country to determine if there are visual, spatial, or statistical relationships between food availability/dietary patterns and CVD. This study focused on diet-related risk factors attributed to increased CVD risk, i.e., a diet high in kilocalories and rich in alcohol, fats, meats, and sugars, and low in fruits and vegetables (21).

\section{MATERIALS AND METHODS}

This study used a correlational design to determine if diet composition-specifically, the number of kilocalories and amount of alcohol, fats, fish, fruits, meats, sugars, and vegetables available per-person daily in each country-is correlated with increased CVD prevalence. The study analyses used country-level data for several reasons: data are most often collected at the country level; country-level data are best suited to mapping; and, since policy decisions are most often made at the country level, the results would be best applied if they too were by-country. An exhaustive search was conducted to locate food and nutrient intake databases available in and for LAC.

\section{Data sources and definitions}

The only databases available contained data on food available per-person, listed as the amount per-person per-day (APD), rather than actual foods consumed by individuals. Even though these databases were not the ones sought for the study, APD is useful for exploring relationships among variables using GIS 
and would add to the body of knowledge regarding diet and CVD. For purposes of this study, the terms "dietary intake" or "dietary availability" refer to the amount of food APD, rather than actual consumption by each individual.

Michigan State University's global access site was used to identify countries for inclusion in the study and defined LAC as a geographic area composed of 47 countries (13) (Table 1). Fifteen of the countries, however, were excluded from the study due to missing dietary or mortality rate data. Therefore, for the purposes of this study, LAC refers to the 32 countries with complete data.

CVD mortality rates. Mortality rates for CVD were obtained from the WHO Statistical Information Systems database under Core Health Indicators (22). CVD mortality rates for each of the 32 countries for the most recent year available, 2002, were downloaded and compiled. Mortality rates were reported as agestandardized number of deaths per 100000 population (22).

Dietary information. Dietary data were obtained from databases located in the food security section of the Food and Agriculture Organization's (FAO) FAOSTAT website (23). Data used were from the period 1995-1997 and represent the amount of food available for human consumption as projected by the FAO food balance sheets. Data sheets used to determine food availability are listed under the food consumption section of the FAOSTAT database (23). Data in this database are collected in a consistent manner from all countries in the world.

The factors chosen for this study were dietary energy (reported in kilocalories APD) and carbohydrate, protein, and fats (reported as a percentage of the total consumption), with availability patterns for each nutrient reported. Food availability patterns were also recorded for specific food groups, (reported in grams of food APD) (23). The diet composition section demonstrating food availability patterns for main food groups were used to further determine if a relationship could be seen between food APD and CVD mortality in each country (23). The main food groups recorded were alcohol, animal fats, cereals, eggs, fish/seafood, fruits, meats, oil-crops, sugars, vegetable oils, and vegetables, all reported in grams of food APD. The above categories were chosen for use in this study based on CVD risk factors related to dietary components (24-26). All dietary information was downloaded and categorized as diet composition of nutrients, total energy availability, and food group available for consumption.

\section{Geographic information systems}

The GIS program ArcGIS 9.2 (Environmental Systems Research Institute, Inc., Redlands, California, United States) was used to determine if there were any visual relationships between CVD and

TABLE 1. The 32 countries of Latin America and the Caribbean included in the study of possible relationships between diet composition in 1995-1997 and cardiovascular mortality in 2002 and the 15 excluded

\begin{tabular}{lll}
\hline & Included & \multicolumn{1}{c}{ Excluded } \\
\hline Argentina & Guyana & Anguilla \\
Bahamas & Haiti & Antigua and Barbuda \\
Barbados & Honduras & Aruba \\
Belize & Jamaica & Bermuda \\
Bolivia & Mexico & Cayman Islands \\
Brazil & Nicaragua & Falkland Islands \\
Chile & Panama & French Guiana \\
Colombia & Paraguay & Guadalupe \\
Costa Rica & Peru & Martinique \\
Cuba & Saint Kitts and Nevis & Montserrat \\
Dominica & Saint Lucia & Netherlands Antilles \\
Dominican Republic & Saint Vincent and the Grenadines & Puerto Rico \\
Ecuador & Suriname & Turks and Caicos \\
El Salvador & Trinidad and Tobago & British Virgin Islands \\
Grenada & Uruguay & United States Virgin Islands \\
Guatemala & Venezuela & \\
\hline
\end{tabular}

the dietary factors. First, a map was created showing CVD mortality rates for the entire LAC area. Then, separate maps were created for each of the dietary risk factors. These were then layered on the CVD map to find any visual relationships between CVD mortality and diet composition. Using the quantile function of the feature class' symbology, the GIS software was used to divide each variable into five levels of nutrient availability, as well as five levels of CVD mortality rates. Nutrient availability was represented using different colors for each of the five categories, with shades of green for low availability and shades of red indicating higher availability. The different visual relationships among the variables can be observed in the maps. CVD mortality rates were represented using the numbers $1-5$, where 1 is the lowest category and 5 is the highest.

The maps were then further analyzed by placing each of the 32 countries into one of four separate categories based on the relationships found between dietary factors and CVD (Table 2).

\section{Statistical analysis}

Descriptive statistics were calculated for the response variable (mortality rates in 2002), as well as all explanatory variables (carbohydrates, proteins, fats, kilocalories, alcohol, animal fats, cereals, eggs, fish, fruits, meats, oil-crops, sugars, vegetable oils, and vegetables in 19951997). A Pearson-product moment correlation coefficient $(r)$ was computed between the response variable and explanatory variables. Significance tests were two-sided with the level of significance set at $P<0.05$. A multiple linear regression analysis was conducted to identify predictors of mortality. Due to the small sample size $(n=32)$, the forward-based stepwise regression procedure was used, and the significance level for entry and removal was $P<0.05$ and $P>0.10$ (27).

\section{RESULTS}

A map was created to show the food APD for each of the following: fish (Figure 1), fruits (Figure 2), total kilocalories (Figure 3), oil-crops (Figure 4), and vegetables (Figure 5). The map showing fish APD (Figure 1), as well as the map with fruit APD, (Figure 2) did not demonstrate a visual relationship between nu- 
TABLE 2. Geographic Information Systems (GIS) map analysis of the relationship between 1995-1997 dietary factors and 2002 cardiovascular disease (CVD) mortality rates in 32 countries of Latin America and the Caribbean

\begin{tabular}{|c|c|c|c|c|}
\hline & $\begin{array}{c}\text { High availability/ } \\
\text { low CVD }\end{array}$ & $\begin{array}{l}\text { High availability/ } \\
\text { high CVD }\end{array}$ & $\begin{array}{c}\text { Low availability/ } \\
\text { low CVD }\end{array}$ & $\begin{array}{c}\text { Low availability/ } \\
\text { high CVD }\end{array}$ \\
\hline Fish & $\begin{array}{l}\text { Bahamas } \\
\text { Chile } \\
\text { Peru } \\
\text { Venezuela }\end{array}$ & $\begin{array}{l}\text { Grenada } \\
\text { Guyana } \\
\text { Saint Kitts and Nevis } \\
\text { Saint Vincent }\end{array}$ & $\begin{array}{l}\text { Colombia } \\
\text { Costa Rica } \\
\text { Ecuador } \\
\text { El Salvador } \\
\text { Guatemala } \\
\text { Mexico } \\
\text { Uruguay }\end{array}$ & $\begin{array}{l}\text { Belize } \\
\text { Brazil } \\
\text { Haiti } \\
\text { Honduras }\end{array}$ \\
\hline Fruit & $\begin{array}{l}\text { Bahamas } \\
\text { Colombia } \\
\text { Costa Rica } \\
\text { Cuba } \\
\text { Ecuador }\end{array}$ & $\begin{array}{l}\text { Belize } \\
\text { Brazil } \\
\text { Dominican Republic } \\
\text { Grenada } \\
\text { Jamaica }\end{array}$ & $\begin{array}{l}\text { Chile } \\
\text { El Salvador } \\
\text { Guatemala } \\
\text { Panama } \\
\text { Peru } \\
\text { Uruguay }\end{array}$ & $\begin{array}{l}\text { Grenada } \\
\text { Haiti } \\
\text { St. Vincent and the } \\
\quad \text { Grenadines } \\
\text { Suriname } \\
\text { Trinidad and Tobago }\end{array}$ \\
\hline Kilocalorie & $\begin{array}{l}\text { Argentina } \\
\text { Chile } \\
\text { Costa Rica } \\
\text { Ecuador } \\
\text { Mexico } \\
\text { Uruguay }\end{array}$ & $\begin{array}{l}\text { Belize } \\
\text { Brazil } \\
\text { Grenada }\end{array}$ & $\begin{array}{l}\text { Bahamas } \\
\text { Cuba } \\
\text { El Salvador } \\
\text { Guatemala } \\
\text { Panama } \\
\text { Peru } \\
\text { Venezuela }\end{array}$ & $\begin{array}{l}\text { Dominican Republic } \\
\text { Haiti } \\
\text { Honduras } \\
\text { Saint Kitts and Nevis } \\
\text { Saint Vincent and the } \\
\text { Grenadines } \\
\text { Trinidad and Tobago }\end{array}$ \\
\hline Oil-crop & El Salvador & $\begin{array}{l}\text { Belize } \\
\text { Brazil } \\
\text { Dominican Republic } \\
\text { Grenada } \\
\text { Guyana } \\
\text { Jamaica } \\
\text { St. Kitts and Nevis } \\
\text { Suriname } \\
\text { Trinidad and Tobago }\end{array}$ & $\begin{array}{l}\text { Argentina } \\
\text { Bahamas } \\
\text { Chile } \\
\text { Cuba } \\
\text { Ecuador } \\
\text { Guatemala } \\
\text { Mexico } \\
\text { Peru } \\
\text { Uruguay } \\
\text { Venezuela }\end{array}$ & Honduras \\
\hline Vegetable & $\begin{array}{l}\text { Argentina } \\
\text { Bahamas } \\
\text { Chile } \\
\text { Cuba } \\
\text { Mexico }\end{array}$ & $\begin{array}{l}\text { Jamaica } \\
\text { Suriname } \\
\text { Uruguay }\end{array}$ & $\begin{array}{l}\text { Costa Rica } \\
\text { Ecuador } \\
\text { El Salvador } \\
\text { Panama }\end{array}$ & $\begin{array}{l}\text { Belize } \\
\text { Dominican Republic } \\
\text { Grenada } \\
\text { Guyana } \\
\text { Haiti } \\
\text { Honduras } \\
\text { St. Vincent and the } \\
\quad \text { Grenadines } \\
\text { Trinidad and Tobago }\end{array}$ \\
\hline
\end{tabular}

Note: all foods or nutrient levels are number of grams of food or nutrient available per-person daily.

trient APD and increased CVD mortality rates because approximately equal numbers of countries were in each of the four categories.

The map showing total kilocalorie APD (Figure 3) did not establish a visual relationship because all four categories had an approximately equal number of countries, except the category with high intake and high CVD rate. This group was expected to contain the largest number of countries, but it actually consisted of only Brazil, Belize, and Grenada. Argentina, Chile, Costa Rica, Ecuador,
Mexico, and Uruguay all had greater kilocalorie APD and lower CVD mortality rates. On the other hand, the $\mathrm{Ba}-$ hamas, Cuba, El Salvador, Guatemala, Panama, Peru, and Venezuela demonstrated that countries with lower kilocalorie APD can also have lower CVD mortality rates.

The oil-crop map (Figure 4) showed the strongest visual relationships. Almost every country fit into one of two categories: high oil-crop APD and high CVD mortality (Belize, Brazil, the Dominican Republic, Grenada, Guyana, Jamaica,
Saint Kitts and Nevis, Suriname, and Trinidad and Tobago) or low oil-crop APD and low CVD mortality (Argentina, the Bahamas, Chile, Cuba, Ecuador, Guatemala, Mexico, Peru, Uruguay, and Venezuela).

The vegetable APD map (Figure 5) also demonstrated strong visual relationships with CVD mortality. Most of the countries fell into one of two categories: high vegetable APD and lower CVD mortality rates (Argentina, Bahamas, Chile, Cuba, and Mexico) or lower vegetable APD and higher CVD mortality rates (Belize, the Dominican Republic, Guyana, Haiti, Honduras, Saint Vincent and the Grenadines, and Trinidad and Tobago).

Descriptive statistics for the response variable (2002 mortality rates) and the explanatory variables (carbohydrates, proteins, fats, kilocalories, alcohol, animal fats, cereals, eggs, fish, fruits, meats, oilcrops, sugars, vegetable oils, and vegetables in 1995-1997) are shown in Table 3. Pairwise Pearson product moment correlation coefficients were calculated between country CVD mortality rates and each of the dietary variables (Table 3 ). Two of the dietary variables were found to have a statistically significant correlation with CVD mortality, with a $P$ value $<0.05$. Fish and seafood APD were positively correlated with CVD mortality ( $r=0.411, P=0.019)$, and oil-crop APD was positively correlated with CVD mortality $(r=0.680, P=0.000)$. There were no statistically significant correlations between any of the remaining variables and CVD mortality $(P>0.05)$.

Results of the multiple linear regression analysis demonstrate that the number of grams of oil-crop APD and kilocalorie APD are statistically significant predictors of a country's annual CVD mortality rate, based on age standardized number of deaths per 100000 population. Oil-crop APD was found to have positive marginal correlation with country CVD mortality rate $(B=3.30,95 \%$ Confidence Interval $(95 \% \mathrm{CI})=2.16-4.44$, $P=0.000$ ), while kilocalorie APD was found to have negative marginal correlation $(B=-0.98,95 \% C I=-0.18--0.02$, $P=0.020)$. Residual analysis indicates the standard normality and homogeneity of variance assumptions are well met and the coefficient of determination $\left(R^{2}=0.525\right)$ indicates that the regression model accounts for approximately 53\% of the variability among countries' CVD mortality rates. 
FIGURE 1. Fish availability in grams per person per day (1995-1997) and cardiovascular disease mortality rate per 100000 population (2002) in Latin America and the Caribbean

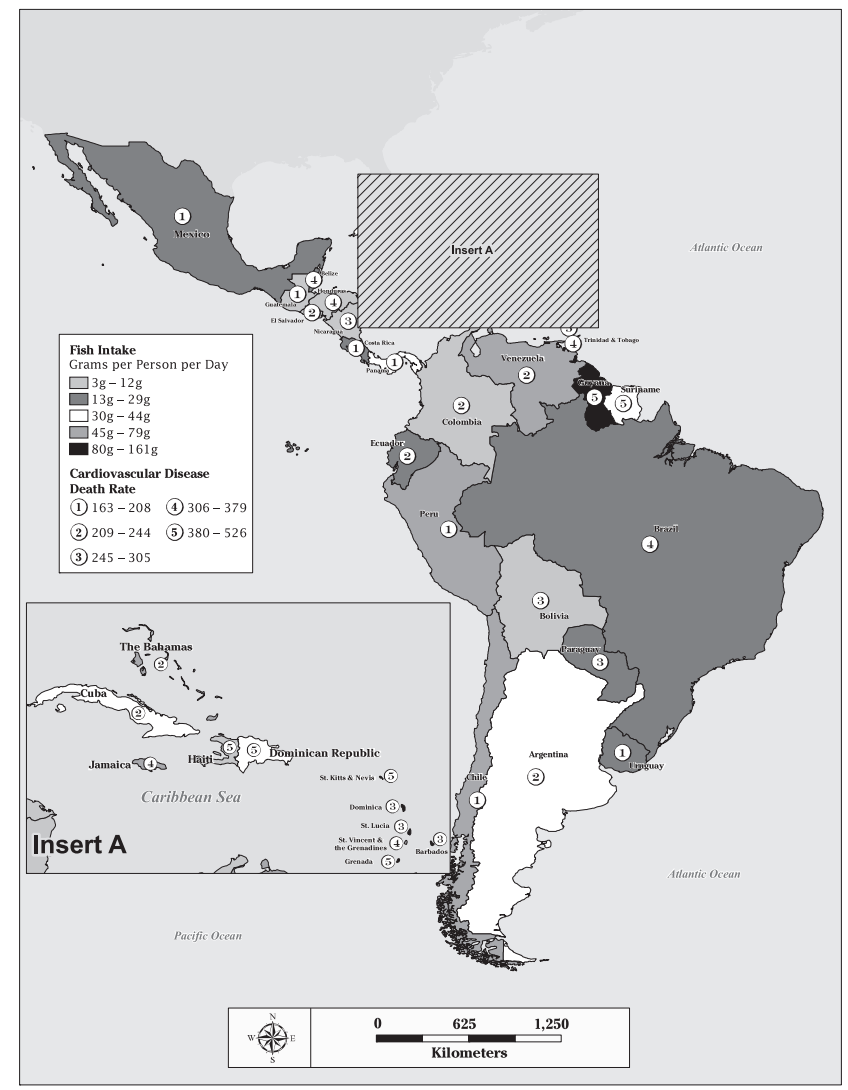

FIGURE 2. Fruit availability in grams per person per day (1995-1997) and cardiovascular disease mortality rate per 100000 population (2002) in Latin America and the Caribbean

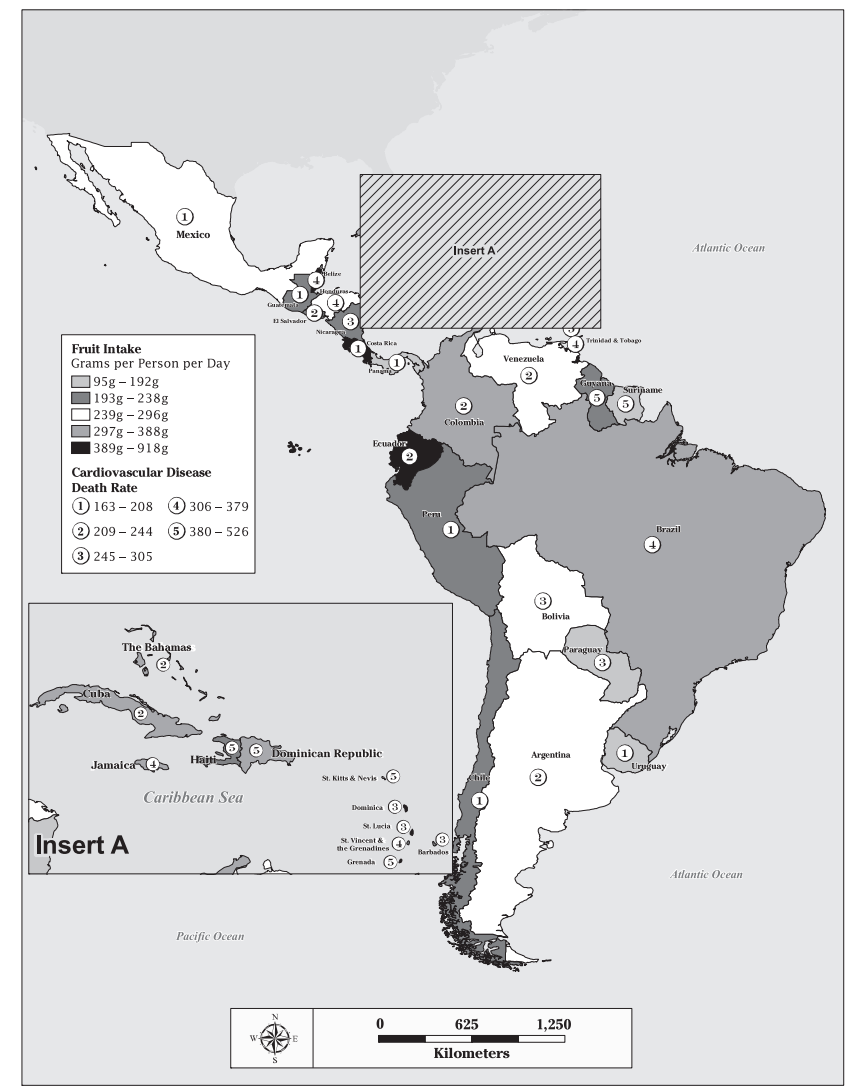

\section{DISCUSSION}

Reddy (15) reported that a higher availability of fruits and vegetables reduces CVD risk. Although there was no statistically significant correlation between vegetables and country CVD mortality found in the present study, a visual relationship was seen on the map showing that high vegetable APD was visually related with low CVD mortality in Argentina, Bahamas, Chile, Cuba, and Mexico. There was low vegetable availability in Belize, the Dominican Republic, Grenada, Guyana, Haiti, Honduras, Saint Vincent and the Grenadines, and Trinidad and Tobago, which were shown to have a higher rate of CVD mortality.

Bermudez and Tucker (8) stated that increased intake of total fats, animal products, and sugar, and decreased intake of fruits and vegetables contribute to increased CVD incidence. Results of the present study did not confirm this, but rather, showed both statistically and visually that alcohol, fruit, meat, and sugar APD were not correlated with CVD mortality. It is difficult to compare results between the Bermudez and Tucker (8) study, which grouped its 22 study countries into six areas to report results, and the present study, which considers the diversity of diets by reporting results individually for its 32 study countries. However, both studies concluded that CVD mortality was high and dietary factors may play a role in these elevated levels.

Reddy and Rivera and colleagues (15, 16) reported that diets rich in fats increase CVD risk. Results of the current study concur: oil-crop APD, which may be an indicator of high fat intake, was statistically and visually related to high CVD mortality rates. The category of oilcrops in the FAOSTAT survey of food availability included oils from coconut, copra, cottonseed, groundnuts, linseed, mustard seed, oilseeds, olives, palm kernel equivalents, rape seeds, sesame seeds, soybeans, and sunflower seeds (22). The strong positive correlation between oil-crop APD and CVD mortality rates found in the present study is due to the high rates of both of these in Belize, Brazil, the Dominican Republic, Grenada, Guyana, Jamaica, Saint Vincent and the Grenadines, Suriname, and Trinidad and Tobago. Although this relationship may not have been expected (since poly- and monounsaturated fatty acids are thought to be cardio-protective), some of the oils listed in the FAOSTAT availability database (22) are high in saturated fatty acids (thought to raise LDL and total cholesterol levels) and may be a risk factor for CVD. However, the present study did not investigate availability of each individual oil-crop to determine which are most frequently used in each country. It might also be expected that countries with lower fat in- 
FIGURE 3. Kilocalorie availability in kilocalories per person per day (1995-1997) and cardiovascular disease mortality rate per 100000 population (2002) in Latin America and the Caribbean

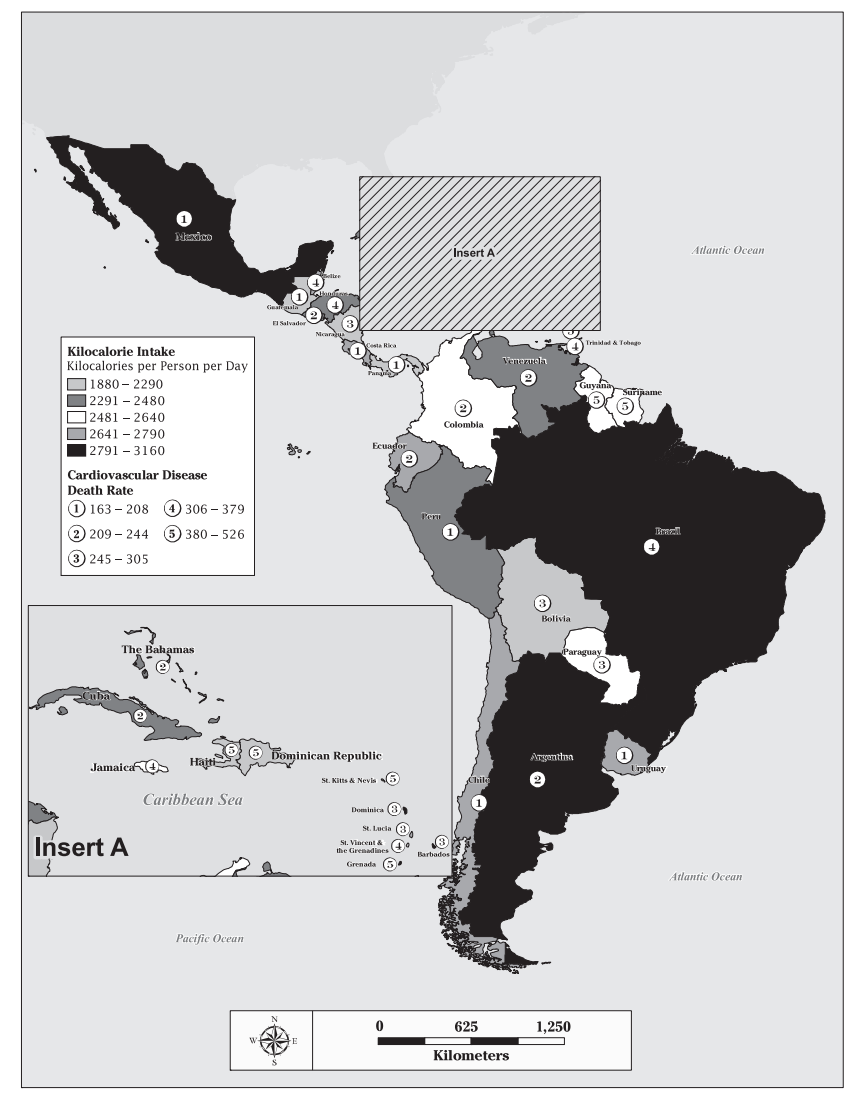

FIGURE 4. Oil crop availability in grams per person per day (1995-1997) and cardiovascular disease mortality rate per 100000 population (2002) in Latin America and the Caribbean

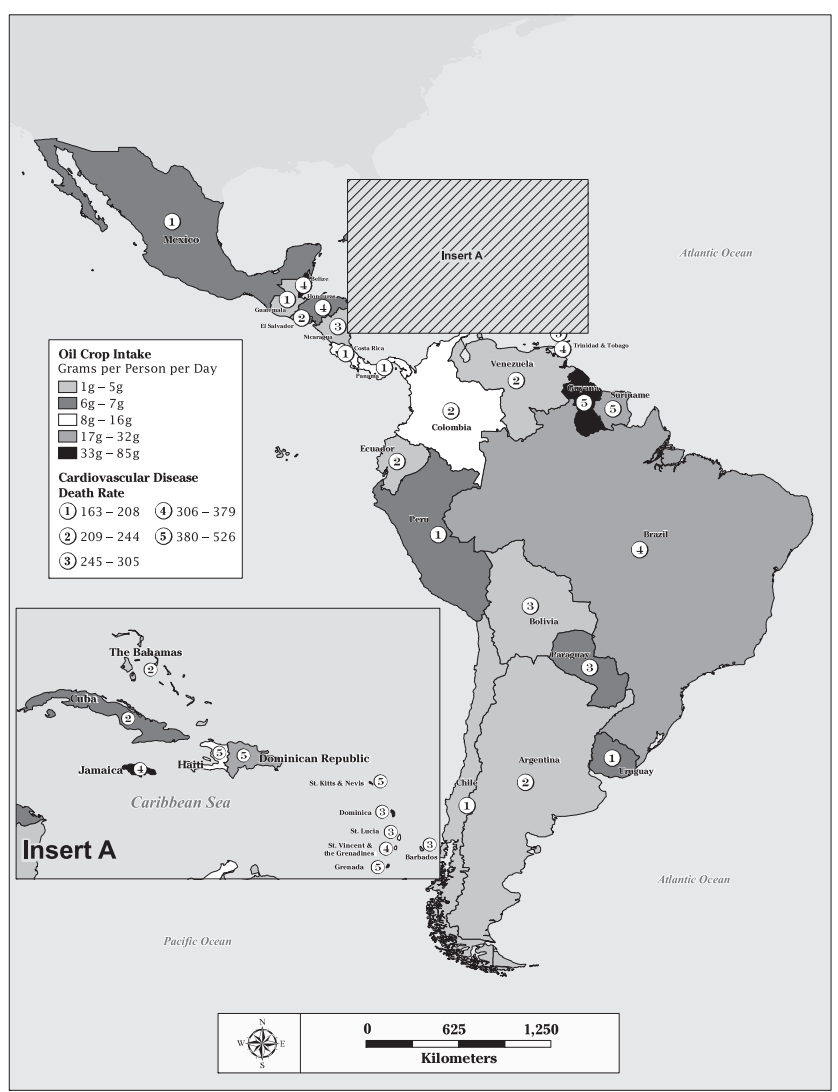

take, represented in this study by lower oil APD, would have a lower incidence of CVD mortality. This was evident in Argentina, the Bahamas, Chile, Cuba, Ecuador, Guatemala, Mexico, Peru, Uruguay, and Venezuela.

The strong positive correlations between fish/seafood APD and CVD mortality, and kilocalorie APD and CVD mortality rates found in the present study were not expected, since fish and seafood are often mentioned as cardioprotective foods, and excess kilocalories are often associated with increased, rather than decreased, CVD risk. Increased fish and seafood APD was correlated with increased CVD mortality rate in Grenada, Guyana, Saint Kitts and Nevis, and Saint Vincent and the Grenadines, and low CVD rates in Colombia, Costa Rica, Ecuador, El Salvador, Guatemala, Mexico, and Uruguay. This was unexpected because previous research has shown that increased fish in- take lowers CVD risk due to its high Omega-3 fatty acid content (26). The American Heart Association (United States) also states that increased fish intake results in decreased serum triglyceride levels, decreased growth rate of atherosclerotic plaque, and slightly lowered blood pressure, which would decrease risk of CVD (28). However, there are potential explanations for these results. The statistically significant pairwise correlation between fish/seafood APD and CVD risk is noteworthy. In the regression model, fish/seafood APD and oil-crop APD were highly correlated with each other, which prevented these from being statistically significant. Both variables could not be included in the regression model because they yielded similar information and multicollinearity makes the slope estimates unreliable. Using fish/seafood, rather than oil-crop, APD provides a model that fits almost as well and is worthy of discussion.
Recent research has explored new possibilities regarding why CVD rates rise with increased fish and seafood consumption $(29,30)$. Studies published within the last 10 years have stated that the methyl-mercury content of fish may cause coronary heart disease, acute myocardial infarction, ischemic heart disease, high blood pressure and hypertensive effects, and alterations in heart rate variability (29). This may explain why the countries with high fish APD have rising CVD mortality rates and those with low fish APD have lower rates. Although the present study was not designed to investigate this, another possible explanation may be that fish cooked in oil-crops high in saturated fatty acids (coconut or palm oils) may not have the same cardio-protective effects.

Kilocalorie APD was shown to be a statistically significant predictor of country CVD mortality rate. This was demonstrated both statistically and visually 
using the maps, with only Belize, Brazil, and Grenada having high kilocalorie APD and increased CVD rates. Argentina, Chile, Costa Rica, Ecuador, Mexico, and Uruguay all demonstrated high kilocalorie APD and low CVD rates. These results were not expected because higher kilocalorie intake usually indicates excess fat and processed foods, which could increase CVD mortality rates. One possibility that may explain these results is that countries with higher kilocalorie APD may be more developed and have hospitals, doctors, and/or programs to prevent and treat CVD. The present study did not focus on this possibility, however. Another possible explanation may be that very low kilocalorie intake and malnutrition in extremely poor areas may not permit an accurate understanding of the relationship between kilocalorie intake and CVD mortality.

\section{Study limitations}

There were some limitations to the present study that have been mentioned or that need to be addressed. Some LAC countries had insufficient dietary and/ or CVD mortality data, and therefore, had to be excluded. So, the entire LAC area was not included. Also, the most recent data for any country was the year 2002; therefore, we were unable to deter-
FIGURE 5. Vegetable availability in grams per person per day (1995-1997) and cardiovascular disease mortality rate per 100000 population (2002) in Latin America and the Caribbean

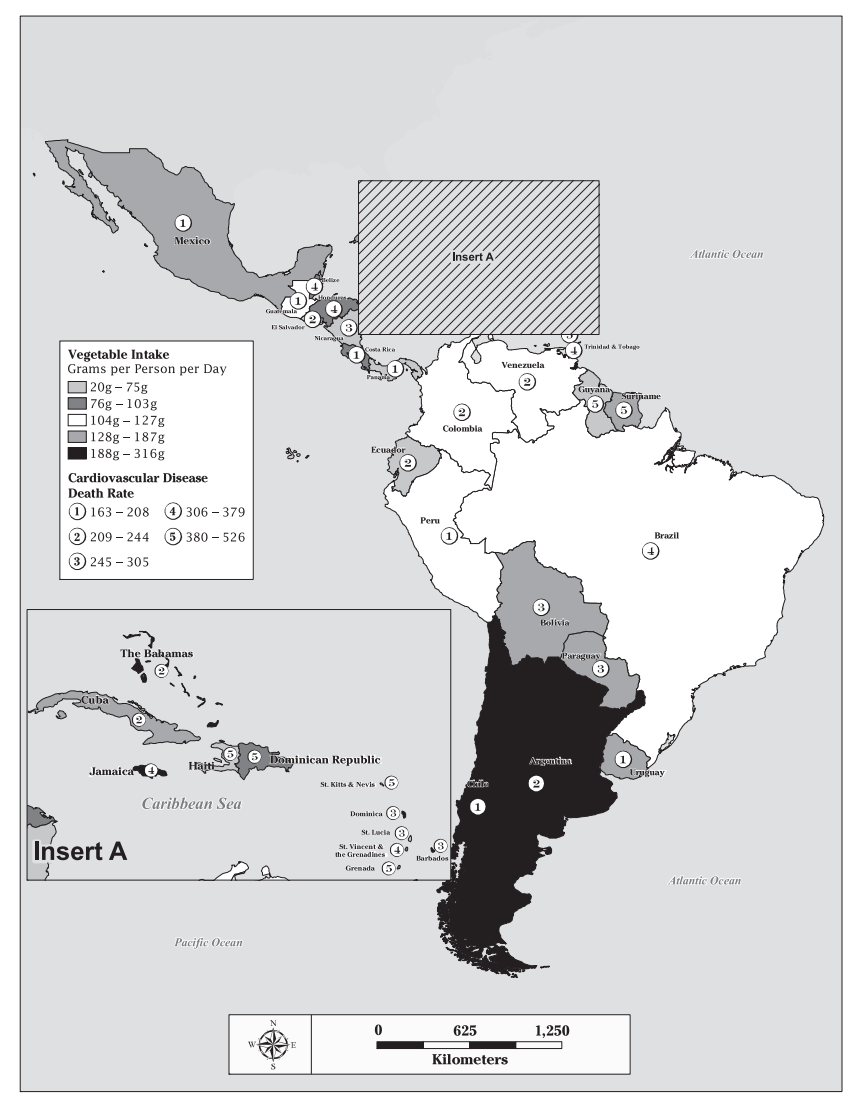

TABLE 3. Descriptive statistics for relationships among cardiovascular disease (CVD) mortality rates in 2002 and food and nutrient availability per-person per-day (APD) in 1995-1997 in Latin America and the Caribbean

\begin{tabular}{|c|c|c|c|c|c|}
\hline & Average & Median & $\begin{array}{l}\text { Standard } \\
\text { deviation }\end{array}$ & $\begin{array}{c}\text { Correlation } \\
\text { with CVD } \\
r\end{array}$ & $\begin{array}{c}\text { Statistical } \\
\text { significance of } \\
\text { correlation, } P\end{array}$ \\
\hline CVD Rate & 286.4 & 258.5 & 92.5 & & \\
\hline \multicolumn{6}{|l|}{ APD } \\
\hline Carbohydrates & 65.0 & 64.5 & 5.6 & 0.119 & 0.517 \\
\hline Protein & 10.5 & 10.0 & 1.3 & -0.151 & 0.409 \\
\hline Fat & 24.5 & 25.0 & 4.8 & -0.093 & 0.615 \\
\hline Alcohol & 94.8 & 88.0 & 51.1 & -0.173 & 0.342 \\
\hline Animal Fat & 8.2 & 8.0 & 5.3 & -0.195 & 0.285 \\
\hline Cereal & 306.7 & 300.5 & 62.0 & -0.253 & 0.162 \\
\hline Eggs & 15.4 & 15.0 & 7.5 & -0.286 & 0.112 \\
\hline Fish & 44.4 & 31.5 & 39.0 & 0.411 & 0.019 \\
\hline Fruit & 307.3 & 262.5 & 170.9 & 0.042 & 0.821 \\
\hline Meat & 132.9 & 119.5 & 67.5 & -0.117 & 0.523 \\
\hline Oil-crops & 19.4 & 13.0 & 21.2 & 0.680 & 0.000 \\
\hline Sugar & 118.9 & 115.5 & 27.8 & -0.012 & 0.947 \\
\hline Oils & 25.7 & 26.5 & 10.8 & -0.047 & 0.798 \\
\hline Vegetables & 126.8 & 108.5 & 67.0 & -0.310 & 0.084 \\
\hline k-calories & 2567.5 & 2585.0 & 295.1 & -0.135 & 0.460 \\
\hline
\end{tabular}

Note: all foods or nutrient levels are number of grams of food or nutrient available per-person daily. 
mine if there have been any recent changes since that time. In addition, the data represented a narrow period of time, so the causal effects of diet that may extend over a lifetime and through a country's epidemiological transition and urbanization as noted by Yusuf and colleagues, could not be determined $(7,31)$.

After an extensive search, it was determined that actual food intake for each of the 32 countries used in the study was not available, therefore food APD was used. This does not account for waste that occurs through factors such as spoilage or plate waste, and may not reflect actual food consumption by individuals. Although it would require a lot of time and money, collection of actual nutrient intake data in each of these countries would be ideal, in order to determine dietary habits. Another limitation is that there are many genetic and environmental risk factors that contribute to the progression of CVD. This study focused on the available dietary data, and not the other factors that may contribute to rising CVD mortality rates in each country.

Because the purpose of this study was to construct maps with dietary and disease databases using GIS technology, the data only allowed for correlation analysis and did not address cause and effect, limiting its application to general audiences.

\section{Recommendations for future research}

In future studies, it would be beneficial to include other important risk factors, such as physical activity levels and smoking habits, since CVD often has multiple etiologies. It is also important that future studies focus on how fish/seafood is being cooked, as well as where it came from, in order to ascertain the mechanisms whereby increased intake may be related to increased CVD mortality. It is possible that a variance in methyl-mercury levels of fish harvested from different bodies of water may help explain the relationship between its consumption and CVD mortality. It is important to conduct additional research that will further our understanding of the factors causing CVD mortality rates to rise. Such knowledge will help design community interventions and treatments that target highrisk groups with behavioral changes that may help lower CVD risk (1).

Future GIS studies that focus on actual dietary intake and geographic location of subjects are needed, as are temporal analyses using GIS techniques to determine the time lag in seeing the effects of diet on CVD risk.

Although the use of group-level data in the present study was necessary because individual data did not exist, the exploratory nature of this study may assist in forming hypotheses for future research. This study should also serve as a stimulus for randomized clinical trials and case-control studies to help determine cause and effect, which are necessary in order to generalize to populations. As emphasized by Ezzati and colleagues (9), nutrition-related risk factors are major contributors to several different types of diseases. Because so many risk factors for CVD have been identified, there is strong justification for investigating intake of specific foods and nutrients as modifiable variables that may reduce disease risk.

\section{Conclusions}

In conclusion, looking at the food APD for each LAC country individually underscores the need for more detailed, country-specific research. The present study showed that fish and seafood, kilocalorie, and oil-crop APD are all related to CVD mortality. The association between these dietary components and CVD mortality rates creates the opportunity to target specific countries and conduct educational programs on high-risk diet patterns and CVD prevention.

Acknowledgements. The authors would like to thank Kenneth R. Brevard, GIS Analyst, for producing the cartography for this project.

\section{REFERENCES}

1. Pearson T. Cardiovascular disease in developing countries: myths, realities, and opportunities. Cardiovasc Drugs Ther. 1999;13: 95-104.

2. Reddy KS, Yusuf S. Emerging epidemic of cardiovascular disease in developing countries. Circulation. 1998;97(6):596-601.

3. Barcelo A. Cardiovascular disease in Latin America and the Caribbean. Lancet. 2006;368: 625-6.

4. Lajolo F. Functional foods: Latin American perspectives. Br J Nutr. 2002;88(Supp 2): S145-50.

5. Yach D, Hawkes C, Gould L, Hofman K. The global burden of chronic diseases: overcoming impediments to prevention and control. JAMA. 2004;291(21):2616-22.

6. Mackay J, Mensah GA. The atlas of heart disease and stroke. Geneva: World Health Organization; 2004. Pp. 24.

7. Yusuf S, Reddy S, Ounpuu S, Anand S. Global burden of cardiovascular diseases: part I: general considerations, the epidemiologic transition, risk factors, and impact of urbanization. Circulation. 2001;104: 2746-53.
8. Bermudez O, Tucker K. Trends in dietary patterns of Latin American populations. Cad Saude Publica. 2003;19(Supp 1):S87-99.

9. Ezzati M, Hoorn SV, Rodgers A, Lopez AD, Mathers CD, Murray CJL, Comparative Risk Assessment Collaborating Group. Estimates of global and regional potential health gains from reducing multiple major risk factors. Lancet. 2003;362:271-80.

10. American Heart Association. Risk factors you can change. [Internet site]. Available from: http://www.americanheart.org/presenter. jhtml?identifier $=494 \#$ cholesterol. . Accessed on 2 April 2009.

11. Nicholls E, Peruga A, Restrepo H. Cardiovascular disease mortality in the Americas. World Health Stat Q. 1993;46:134-50.

12. Dominguez L, Barbagallo $M$, Sowers J. Cardiovascular risk factors in South America and the Caribbean. Ethn Dis. 1999;9:468-78.

13. MSU Global Access. Latin America and the Caribbean [Internet site]. Available from: http://www.msuglobalaccess.net/geo/ latinamerica/. Accessed on 18 April 2007.

14. Greenberg M, Schneider D, Northridge M, Ganz M. Public health briefs. Region of birth and black diets: the Harlem household survey. Am J Public Health. 1998;88(8): 1199-202.

15. Reddy K. Cardiovascular disease in nonwestern countries. N Engl J Med. 2004;350 (24):2438-40.

16. Rivera J, Barquera S, Gonzalez-Cossio T, Olaiz G, Sepulveda J. Nutrition transition in Mexico and in other Latin American countries. Nutr Rev. 2004;62(7):1-8.

17. National Center for Health Statistics. GIS and Public Health Page. 2007. [Internet site]. Available from: http://www.cdc.gov/nchs / gis.htm. Accessed on 20 July 2007.

18. Brown D. Mapping the future of dietetics with geographic information systems. J Am Diet Assoc. 2004;104(5):727-8.

19. Schlundt D, Mushi C, Larson C, Marrs M. Use of innovative technologies in the evaluation of Nashville's REACH 2010 community action plan: reducing disparities in cardiovascular disease and diabetes in the African American community. J Ambul Care Manage. 2001;24(3):51-60.

20. Richards T, Croner C, Rushton G, Brown C, Fowler L. Geographic information systems 
and public health: mapping the future. Public Health Rep. 1999;114:359-73.

21. American Heart Association. Risk factors and coronary heart disease [Internet site]. Available from: http://www.americanheart.org/ presenter.jhtml?identifier $=500 \#$ obesity. Accessed on 24 November 2006.

22. World Health Organization. Core health indicators [Internet site]. Available from: http:// www.who.int/whosis/database/core/core select process.cfm. Accessed on 15 October 2007.

23. Food and Agricultural Organization of the United Nations. Food Security Statistics [Internet site]. Available from: http://www.fao. org/economic/ess/food-security-statistics/ en/. Accessed on 15 April 2007.

24. World Health Organization. The world health report 2002: reducing risks, promoting healthy life. Geneva: WHO; 2002. Available from: http://www.who.int/whr/2002/ chapter4/en/index4.html. Accessed on 1 March 2008.

25. Center for Disease Control and Prevention. Heart disease risk factors [Internet site]. Available from: http://www.cdc.gov/heart disease/risk_factors.htm. Accessed on 1 March 2007.

26. American Heart Association. Risk factors and coronary heart disease [Internet site]. Available from: http://www.americanheart.org/ presenter.jhtml?identifier $=4726$. Accessed on 1 March 2008.

27. Guyatt G, Walter S, Shannon H, Cook D, Jaeschke R, Heddle N. Basic statistics for clinicians: 4. correlation and regression. Can Med Assoc J. 1995;152(4):497-504.

28. American Heart Association. Fish and omega-3 fatty acids [Internet site]. Available from: http://www.americanheart.org/ presenter.jhtml?identifier $=4632$. Accessed on 1 March 2008.
29. Mergler D, Anderson H, Chan L, Mahaffey K, Murray M, Sakamoto M, et al. Methylmercury exposure and health effects in humans: a worldwide concern. Ambio. 2007;36: 1-11.

30. Guallar E, Sanz-Gallardo M, Veer P, Bode P, Aro A, Gomez-Aracena J, et al. Mercury, fish oils, and the risk of myocardial infarction. $\mathrm{N}$ Engl J Med. 2002;347(22):1747-54.

31. Yusuf S, Reddy S, Ounpuu S, Anand S. Global burden of cardiovascular diseases: part II: variations in cardiovascular disease by specific ethnic groups and geographic regions and prevention strategies. Circulation. 2001;104:2855-64.

Manuscript received on 31 October 2008. Revised version accepted for publication on 27 April 2009.
RESUMEN

Vinculación de la dieta con la enfermedad cardiovascular en América Latina y el Caribe mediante sistemas de información geográfica

Palabras clave
Objetivos. Determinar la relación visual, espacial y estadística entre los patrones dietéticos y de disponibilidad alimentaria, y la enfermedad cardiovascular (ECV) en América Latina y el Caribe.

Métodos. Las kilocalorías y la cantidad de alcohol, grasas, pescado, frutas, carnes, azúcar y vegetales disponibles por persona diariamente, las tasas de mortalidad por ECV y la información dietética se obtuvieron de bases de datos internacionales. El análisis abarcó 32 de los 47 países latinoamericanos y caribeños con datos suficientes (se excluyeron 15 países por datos incompletos). Se determinó la relación entre la dieta y la mortalidad por ECV mediante el análisis de correlación de Pearson $(r)$ y se identificaron los factores de predicción de la mortalidad mediante el análisis de regresión lineal múltiple. Se elaboraron mapas para explorar las relaciones visuales entre la ECV y la dieta con el programa ArcGIS 9.2 (Environmental Systems Research Institute, Inc., Redlands, California, Estados Unidos de América).

Resultados. No se encontró relación entre la ECV y el consumo de alcohol, frutas, carnes, azúcar o vegetales. Se observó una correlación directa significativa entre la mortalidad por ECV y el consumo de cultivos oleaginosos $(r=0,680 ; P<0,001)$ y pescados y mariscos $(r=0,411 ; P=0,019)$. El análisis de regresión reveló que la elevada disponibilidad calórica fue un factor de predicción de baja mortalidad por ECV $(P=0,020)$, mientras la alta disponibilidad de cultivos oleaginosos fue un factor de predicción de elevada mortalidad por ECV $(P<0,001)$. Los mapas elaborados mostraron relaciones visuales entre la disponibilidad de pescados y mariscos, kilocalorías y cultivos oleaginosos, por una parte, y la mortalidad por ECV por la otra.

Conclusiones. La disponibilidad de pescados y mariscos, kilocalorías y cultivos oleaginosos parece estar relacionada con la mortalidad por ECV, pero se necesitan estudios adicionales. Las asociaciones entre la dieta y la mortalidad por ECV abren la posibilidad de identificar países concretos en los que implementar programas de educación nutricional y de prevención de ECV.

Enfermedades cardiovasculares; dieta; consumo de alimentos; sistemas de información geográfica; mortalidad; América Latina; Región del Caribe. 